\title{
Marine protected areas in South AMerica: SPATIAL ASSESSMENT OF CETACEAN DISTRIBUTION COVERAGE
}

\author{
Andrés GómeZ ${ }^{1,+, *}$ AND Martín MendeZZ ${ }^{1,2,+}$
}

KeYwords: Marine protected areas, cetaceans, South America.

Recent attention to the great biological diversity of the world's oceans and the serious threats it currently faces has garnered support for the establishment of marine protected areas (MPAs) (Lovejoy, 2006), defined by the World Conservation Union (IUCN) as "any area of intertidal or subtidal terrain, together with its overlying water and associated flora, fauna, historical and cultural features, which has been reserved by law or other effective means to protect part or all of the enclosed environment" (Hoyt, 2005). Recent evidence suggests that MPAs can effectively contribute to the conservation of biological resources and the economic activities that depend on them (Behrens and Lafferty, 2004; Floeter et al., 2006; Guidetti, 2007). Consequently, although the number of MPAs has increased dramatically in recent years, the creation of new ones is still considered a priority (Mora et al., 2006; Remington et al., 2007).

In the context of the expansion of national protected area networks, spatially explicit analyses of current coverage help identify major gaps and therefore to guide the establishment, design and management of new reserves. However, to date, most such analyses have been done for the terrestrial realm (Rodrigues and Gaston, 2001; Scott et al., 2001; Sanderson et al., 2002; Rodrigues et al., 2004). Although MPAs worldwide have largely proven successful in protecting marine taxa and habitats (Guenette et al., 1998; Halpern, 2003), the appropriateness of existing MPAs to adequately protect cetaceans may be limited (Reeves, 2000).

Typical MPAs are too small to offer adequate coverage for cetaceans, as these are species characterized by high dispersal capabilities (Hoelzel, 1994). As a consequence of their migratory behavior and complex habitat requirements, cetaceans have been proposed as 'umbrella species' that could be used to strategically create MPAs capable of offering coverage to both these marine mammals and a variety of other marine species with less extensive dispersal requirements (Hooker and Gerber, 2004). South America (SA) holds a significant fraction of the world's marine biological diversity, which includes at least 48 cetacean species (Table 1). Protected area systems in SA are extensive, but the degree to which they represent species and major terrestrial ecological units is varied and critical gaps still exist (Esty et al., 2006; Soutullo and Gudynas, 2006). Here, we analyze the degree to which MPAs in SA cover the ranges of cetacean species. Since conservation policy is normally planned and executed at the national level, and because legislation and enforcement are problematic in international waters, we limited our analysis to the exclusive economic zones (EEZ; 200 nautical miles from the shore, as defined by the United Nations Law of the Sea Convention) of all coastal countries in SA, namely: Argentina, Brazil, Chile, Colombia, Ecuador, French Guiana, Guyana, Peru, Suriname, Uruguay and Venezuela. We collected distribution information for the 48 cetacean species present within these national waters. To minimize species distribution inaccuracies from particular sources, we integrated data from the Marine Mammals of the World section of the World Biodiversity Database (http:/ / nlbif.eti.uva.nl/bis/ index.php) and from three widely used marine mammal field guides (Carwardine, 1999; Reeves et al., 2002; Reeves et al., 2003). When a species' range differed among the different sources, we considered the broadest distribution limits as a conservative estimate. A potential caveat is that species occurrence data recorded in these sources may be incomplete and therefore fine-scale observations must also be considered when using analyses such as this one to delineate conservation strategies.

We compiled a list of MPAs in SA using the MPA Global database (http://www.mpaglobal.org, accessed 15 March 2007) and included in this analysis all MPAs present in its database regardless of their IUCN category and the completeness of the associated information, except when spatial coordinates or total area information were unavailable. Our initial database contained 166 MPAs. We then collated this list with the 2006 World Database on Protected Areas (UNEPWCMC, 2006) and obtained boundary polygons when available. For those areas in which only point data were available, we drew a circular polygon on the appropriate area around the central coordinates. We calculated the area of each MPA situated over the water (i.e. beyond the continent coastline, including estuaries and deltas) and used this fraction to estimate the coverage provided to each species (percent coverage, Table 1).

\footnotetext{
${ }^{1}$ Columbia University Department of Ecology, Evolution and Environmental Biology, New York, NY, USA.

${ }^{2}$ Sackler Institute for Comparative Genomics at the American Museum of Natural History (AMNH).

Ocean Giants Program at Wildlife Conservation Society.

Fundación Aquamarina, CECIM, Argentina.

+ Both authors contributed equally to this publication.

* Corresponding author, e-mails: ag2112@columbia.edu, agomezmejia@gmail.com. Department of Environmental Ecology and Evolutionary Biology, Columbia University, 1200 Amsterdam Avenue MC5557, New York, NY 10027 USA. Phone: (212) 854 - 9987; fax: (212) 854 - 8188; mobile: (917) 331 - 2408.
} 
Table 1. Percent coverage provided to cetacean species in South America by the current marine protected area network. Fields marked by an asterisk $\left(^{*}\right)$ reflect pooled information for more than one species, subspecies or form, since exact distribution data are lacking. Minke whale's data reflect coverage for both subspecies (B. bonaerensis and B. acutorostrata). Common dolphin's coverage is pooled for both long-beaked common dolphin (D. capensis) and short-beaked common dolphin (D. delphis) data. Both the tucuxi and Guiana dolphin are pooled under Sotalia spp.

\begin{tabular}{|c|c|c|c|}
\hline SCIENTIFIC NAME & COMMON NAME & " CONSERVATION STATUS ${ }^{A}$ & \% COVERAGE \\
\hline Phocoena dioptrica & Spectacled porpoise & Data defficient & 0.14 \\
\hline Balaenoptera bonaerensis $\left(^{*}\right)$ & Minke whale & Lower risk (LC) & 1.93 \\
\hline Balaenoptera borealis & Sei whale & Endangered & 1.93 \\
\hline Balaenoptera edeni & Bryde's whale & Data defficient & 1.93 \\
\hline Balaenoptera musculus & Blue whale & Endangered & 1.93 \\
\hline Balaenoptera physalus & Fin whale & Endangered & 1.93 \\
\hline Berardius arnuxii & Arnoux's beaked whale & Lower risk (CD) & 0.09 \\
\hline Caperea marginata & Pygmy right whale & Lower risk (LC) & 0.09 \\
\hline Cephalorhynchus commersonii & Commerson's dolphin & Data defficient & 0.10 \\
\hline Cephalorhynchus eutropia & Chilean dolphin & Data defficient & 0.06 \\
\hline Delphinus spp. $\left({ }^{*}\right)$ & Common dolphin & Lower risk (LC) & 1.93 \\
\hline Eubalaena australis & Southern right whale & Lower risk (CD) & 0.25 \\
\hline Feresa attenuata & Pygmy killer whale & Data defficient & 2.61 \\
\hline Globicephala macrorhynchus & Short-finned pilot whale & Lower risk $(\mathrm{CD})$ & 2.68 \\
\hline Globicephala melas & Long-finned pilot whale & Lower risk (LC) & 0.09 \\
\hline Grampus griseus & Risso's dolphin & Data defficient & 1.93 \\
\hline Hyperoodon planifrons & Southern bottlenose whale & Lower risk (CD) & 0.08 \\
\hline Kogia breviceps & Pygmy sperm whale & Lower risk (LC) & 2.48 \\
\hline Kogia sima & Dwarf sperm whale & Lower risk (LC) & 3.05 \\
\hline Lagenodelphis hosei & Fraser's dolphin & Data defficient & 3.79 \\
\hline Lagenorhynchus australis & Peale's dolphin & Data defficient & 0.14 \\
\hline Lagenorhynchus cruciger & Hourglass dolphin & Lower risk (LC) & 0.09 \\
\hline Lagenorhynchus obscurus & Dusky dolphin & Data defficient & 0.11 \\
\hline Lissodelphis peronii & Southern right whale dolphin & Data defficient & 0.10 \\
\hline Megaptera novaeangliae & Humpback whale & Vulnerable & 1.93 \\
\hline Mesoplodon densirostris & Blainville's beaked whale & Data defficient & 2.23 \\
\hline Mesoplodon europaeus & Gervais' beaked whale & Data defficient & 0.98 \\
\hline Mesoplodon ginkgodens & Ginkgo-toothed beaked whale & Data defficient & 9.85 \\
\hline Mesoplodon grayi & Gray's beaked whale & Data defficient & 0.22 \\
\hline Mesoplodon hectori & Hector's beaked whale & Data defficient & 0.15 \\
\hline Mesoplodon layardii & Strap-toothed whale & Data defficient & 0.08 \\
\hline Mesoplodon peruvianus & Lesser beaked whale & Data defficient & 3.73 \\
\hline Orcinus orca & Killer whale & Lower risk (CD) & 1.93 \\
\hline Peponocephala electra & Melon-headed whale & Lower risk (LC) & 3.89 \\
\hline Phocoena spinipinnis & Burmeister's porpoise & Data defficient & 0.16 \\
\hline Physeter macrocephalus & Sperm whale & Vulnerable & 1.93 \\
\hline Pontoporia blainvillei & Franciscana dolphin & Data defficient & 0.53 \\
\hline Pseudorca crassidens & False killer whale & Lower risk (LC) & 2.45 \\
\hline Sotalia spp. $\left({ }^{*}\right)$ & Tucuxi/Guiana dolphin & Data defficient & 1.73 \\
\hline Stenella attenuata & Pantropical spotted dolphin & Lower risk $(\mathrm{CD})$ & 2.96 \\
\hline Stenella clymene & Clymene dolphin & Data defficient & 1.23 \\
\hline Stenella coeruleoalba & Striped dolphin & Lower risk $(\mathrm{CD})$ & 2.89 \\
\hline Stenella frontalis & Atlantic spotted dolphin & Data defficient & 1.29 \\
\hline Stenella longirostris & Spinner dolphin & Lower risk $(\mathrm{CD})$ & 3.71 \\
\hline Steno bredanensis & Rough-toothed dolphin & Data defficient & 3.10 \\
\hline Tasmacetus shepherdi & Shepherd's beaked whale & Data defficient & 0.14 \\
\hline Tursiops truncatus & Common bottlenose dolphin & Data defficient & 3.23 \\
\hline Ziphius cavirostris & Cuvier's beaked whale & Data defficient & 1.93 \\
\hline
\end{tabular}

a Data from www.redlist.org, accessed March 15 2007. LC: Least concern, CD: Conservation dependent. 
Our final database contained littoral and sublittoral components of 143 MPAs. To reduce the magnitude of spatial errors that might lead to overestimation, we removed all resulting polygons of less than $1 \mathrm{~km}^{2}$ (these polygons belonged to 24 MPAs or $16.7 \%$ of the MPAs in our final database). We then estimated the percentage of the range of each species that is included in a protected area.

We found that a significant fraction of the areas listed in the MPA database we consulted had no jurisdiction beyond the intertidal zone. MPAs in our database generally included small areas that in total covered less than $3.5 \%$ of the EEZs in SA. Only three MPAs included ocean areas larger than $10000 \mathrm{~km}^{2}$ whereas $40 \%$ had areas of less than $10 \mathrm{~km}^{2}$. Finally, although management and enforcement in the open ocean are essential given the high connectivity in marine systems (Cawardine, 2002; Hoyt, 2005; Norse, 2005), in this case exemplified by inshore and offshore cetacean stocks or populations (Palumbi, 2003; Norse, 2005), there were currently no established high-seas MPAs in the region (i.e. protected areas that do not share a border with a terrestrial component, whether continental or insular).

Not surprisingly, cetacean distribution ranges were minimally covered by MPAs in SA. Across all species, the average percentage of the cetacean range included in a MPA was $1.7 \%$ (range $0.06-9.8 \%$ ). A total of 19 species had less than $1 \%$ of their range covered in the current MPA system, including nine species whose ranges have less than $0.1 \%$ coverage (Table 1 ). Further, we found that the average range coverage for endemic species $(0.45 \%)$ was lower than the average for all species and was independent of conservation status (Table 1). It is important to note that the overall inclusion levels (e.g. the total percentage of the range that is included in a MPA) reported here do not explicitly account for the number of individual polygons that contribute to the total area under protection. Given the small size of most oceanic polygons in MPAs in SA (as above, the protected fractions that extend beyond the shore), the percentage of inclusion of a species' range is overwhelmingly represented by the sum of several small areas. This fragmentation of protected areas can further limit their conservation potential for cetaceans. Taken together, these results indicate that cetaceans are inadequately represented in MPA networks in SA. Those species that are considered as endangered, vulnerable or data deficient, as well as the endemic species (Table 1) could serve as a starting point in identifying candidates for conservation priorities in the region.

Mapped boundaries were absent in a large fraction $(48.5 \%)$ of the MPAs included in this analysis, as was information about management, regulation and zoning. Zoning regimes delineate different conservation goals and regulations within the boundaries of some protected areas, resulting in different levels of protection afforded to cetacean species and their habitats within each of our mapped polygons. Since we treated all polygons in this analysis as a uniform conservation unit, strict protection of cetacean ranges is overestimated in our results. Although we do not expect any significant effect on our results given the low coverage afforded to cetaceans, any bias introduced by such overestimation would be small and would only reinforce our conclusions. However, species' distributions are not uniform throughout their ranges and MPAs in the region may contain critical areas (e.g. feeding or mating grounds), which would increase their conservation value in spite of a relatively small area protected. In the absence of more detailed spatially defined datasets, analyses such as this one necessarily incorporate errors, both of omission and commission; we hope that in the future national environmental authorities will refine and update their datasets, but suggest that qualitatively our conclusions remain valid.

Given the multi-factorial nature of the current threats faced by cetaceans, MPAs represent only one approach to cetacean conservation. For instance, the most recent assessment of South American small cetacean species by the International Whaling Commission (IWC) highlighted the need for information on abundance, distribution, population structure, life history and habitat of these taxa (IWC, 2009). The theory underlying the design of MPAs is in its infancy and remains context dependent (Botsford et al., 2003; Gerber et al., 2003; IWC, 2009); moreover, with few exceptions, most MPAs are not typically designed to protect cetaceans specifically (Hoyt, 2005). In any plan to expand current levels of protection, it is necessary to carefully balance the need for larger areas under protection with actual capacity for enforcement, and consideration to whether increasing the number of MPAs and the total area under protection provides added benefits to the protection granted by other means. At a local scale, future MPAs aimed at conserving cetaceans would benefit from cetacean habitat preference assessments and modeling efforts that identify potential areas of higher occurrence and abundance (Reilly, 1990; Reilly and Fiedler, 1994; Baumgartner et al., 2001; Davis et al., 2002; Redfern et al., 2006). Important issues related to cetacean demography in the context of a complex and dynamic environment could be best approached by integrating data across disciplines (Palumbi, 2003; Palumbi et al., 2003). For instance, in cetaceans, genetic approaches offer high resolution to characterize population structure, connectivity, and identify management units (Hoelzel, 1998; DeSalle, 2004), which could be further enhanced by detailed oceanographic information to contextualize such assessments. Data on seafloor physiographic features, bathymetry, marine productivity and sea surface temperature, among other oceanographic features, have proven relevant to pinpoint areas of potential population subdivision in cetaceans (Fullard et al., 2000; Wares et al., 2001; Elwen and Best, 2004a, b; Norse, 2005; Rosa et al., 2005; Mendez et al., 2008). Although not yet legally established in the region, highseas reserves may be particularly relevant, as these areas 
play important roles in the origin and maintenance of marine biodiversity. Pelagic fisheries, migratory species and top predators currently impacted in the high seas have a profound impact on coastal ecosystems through massive species removal and trophic web alteration (Reeves, 2000; Dans et al., 2003; Amaral and Jablonski, 2005; Fernandez and Castilla, 2005). Current efforts for high-seas conservation in the region include the Sea and Sky project in the South Atlantic, which seeks to protect an outstandingly large area between the $30^{\circ} \mathrm{S}$ and $60^{\circ} \mathrm{S}$, and extending from the east coast of South America to $50^{\circ} \mathrm{W}$ (http:/ / sea-sky.org). In addition, a recent proposal to the IWC by the Governments of Argentina, Brazil and South Africa seeks to establish a whale sanctuary delimited by the Equator to the north, the coasts of South America and Africa to the east and west, and a southern boundary varying between $40^{\circ} \mathrm{S}$ at its easternmost point and $60^{\circ} \mathrm{S}$ at its western limit (Truda Palazzo et al., 2008). Cetaceans in South America suffer from a variety of threats that seriously compromise their persistence, including intentional and incidental catch and entanglement, habitat alteration, prey removal, noise and chemical pollution, collisions with vessels and climate change (Dans et al., 2003; Amaral and Jablonski, 2005; Fernandez and Castilla, 2005). Despite these conspicuous threats, which vary in intensity and by species, there is a lack of rigorous research and appropriate reporting of the status of a significant fraction of the species in the region (Table 1) (IUCN, 2006). Due to its spatial distribution and limited overall area, the current MPA network in SA likely provides few real conservation benefits to cetaceans in the region. To achieve full representation and adequate area coverage of cetacean species, MPA site selection and design should respond to the conservation a series of hierarchical ecological processes in space, from demographic stability and connectivity at the population level, to multispecies interactions, to oceanographic processes controlling species distribution and abundance in an appropriate ecoregional framework.

\section{Acknowledgments}

Both authors are supported by Columbia University Graduate School of Arts and Sciences Faculty Fellowships and the Whitley Fund for Nature. E. Nichols improved an earlier version of this manuscript. An anonymous reviewer, Ms. Mônica Borobia and Mr. Daniel Palacios provided useful comments that enhanced this article.

\section{References}

AmARAL, A.C.Z. AND JABLONSKI, S. (2005) Conservation of marine and coastal biodiversity in Brazil. Conservation Biology 19(3): 625-631.

Baumgartner, M.F., Mullin, K.D., May, L.N. And Leming, T.D. (2001) Cetacean habitats in the northern Gulf of Mexico. Fishery Bulletin 99(2): 219-239.
BEHRENS, M.D. AND LAFFERTY, K.D. (2004) Effects of marine reserves and urchin disease on southern Californian rocky reef communities. Marine Ecology Progress Series 279: 129-139.

Botsford, L.W., Micheli, F. And Hastings, A. (2003) Principles for the design of marine reserves. Ecological Applications 13(1): S25-S31.

Carwardine, M. (1999) Whales, dolphins, and porpoises. New York, NY, Checkmark Books.

Cawardine, M., (Ed). (2002) Whales, Dolphins, and Porpoises. Smithsonian Handbooks. New York, Dorling Kindersley Books.

Dans, S.L., Alonso, M.K., Pedraza, S.N. And Crespo, E.A. (2003) Incidental catch of dolphins in trawling fisheries off Patagonia, Argentina: Can populations persist? Ecological Applications 13(3): 754-762.

Davis, R.W., Ortega-Ortiz, J.G., Ribic, C.A., Evans, W.E., Biggs, D.C., Ressler, P.H., Cady, R.B., Leben, R.R., Mullin, K.D. And Wursig, B. (2002) Cetacean habitat in the northern oceanic Gulf of Mexico. Deep-Sea Research 49(1): 121-142.

DeSalle, R. and Amato, G. (2004) The expansion of conservation genetics. Nature Review Genetics 5: 702-713.

Elwen, S.H. AND Best, P.B. (2004a) Environmental factors influencing the distribution of southern right whales (Eubalaena australis) on the south coast of South Africa I: Broad scale patterns. Marine Mammal Science 20(3): 567-582.

Elwen, S.H. ANd Best, P.B. (2004b) Environmental factors influencing the distribution of southern right whales (Eubalaena australis) on the south coast of South Africa II: Within bay distribution. Marine Mammal Science 20(3): 583-601.

Esty, D.C., Levy, M.A., Srebotnjak, T., Sherbinin, A. De, Kim, C.H. AND Anderson, B. (2006) Pilot 2006 Environmental Performance Index. New Haven, CT, Yale Center for Environmental Law \& Policy, New Haven, CT, USA.

Fernandez, M. and Castilla, J.C. (2005) Marine Conservation in Chile: Historical Perspective, Lessons, and Challenges. Conservation Biology 19(6): 1752-1762.

Floeter, S.R., Halpern, B. S. AND Ferreira, C.E.L. (2006) Effects of fishing and protection on Brazilian reef fishes. Biological Conservation 128(3): 391-402.

Fullard, K., Early, G., Heide-Jorgensen, M., Bloch, D., RosingAsvid, A. And Amos, W. (2000) Population structure of long-finned pilot whales in the North Atlantic: a correlation with sea surface temperature? Molecular Ecology 9(7): 949-958.

Gerber, L.R., Botsford, L.W., Hastings, A., Possingham, H.P., Gaines, S.D., Palumbi, S.R. And Andelman, S. (2003) Population models for marine reserve design: A retrospective and prospective synthesis. Ecological Applications 13(1): S47-S64.

Guenette, S., Lauck, T. And Clark, C. (1998) Marine reserves: from Beverton and Holt to the present. Reviews in Fish Biology and Fisheries 8(3): 251-272.

Guidetti, P. (2007) Potential of marine reserves to cause community-wide changes beyond their boundaries. Conservation Biology 21(2): 540-545.

HALPERN, B.S. (2003) The impact of marine reserves: Do reserves work and does reserve size matter? Ecological Applications 13(1): S117-S137.

Hoelzel, A. (1994) Genetics and ecology of whales and dolphins. Annual Review of Ecology and Systematics 25: 377-399.

Hoelzel, A.R. (1998) Genetic structure of cetacean populations in sympatry, parapatry, and mixed assemblages: Implications for conservation policy. Journal of Heredity 89(5): 451-458. 
HOOKER, S.K. AND GERBER, L.R. (2004) Marine reserves as a tool for ecosystem-based management: The potential importance of megafauna. Bioscience 54(1): 27-39.

Hoyt, E. (2005) Marine Protected Areas For Whales Dolphins and Porpoises: A World Handbook for Cetacean Habitat Conservation. London, Earthscan, London, UK.

IWC (2009) Report of the Scientific Committee. Annex L. Report of the Sub-Committee on Small Cetaceans. Journal of Cetacean Research and Management (Suppl.) 11: 311-333.

Lovejoy, T.E. (2006) Protected areas: a prism for a changing world. Trends in Ecology \& Evolution 21(6): 329-333.

Mendez, M., Rosenbaum, H.C. And Bordino, P. (2008) Conservation genetics of the franciscana dolphin in Northern Argentina: population structure, by-catch impacts, and management implications. Conservation Genetics 9(2): 419-435.

Mora, C., Andrefouet, S., Costello, M.J., Kranenburg, C., Rollo, A., Veron, J., Gaston, K.J. And Myers, R.A. (2006) Coral reefs and the global network of marine protected areas. Science 312(5781): 1750-1751.

Norse, E.A. AND CROWDER, L.B. (2005) Marine Conservation Biology: The Science of Maintaining the Sea's Biodiversity. Washington, Island Press.

Palumbi, S.R. (2003) Population genetics, demographic connectivity, and the design of marine reserves. Ecological Applications 13(1): S146-S158.

Palumbi, S. ., Gaines, S.D., Leslie, H. And Warner, R.R. (2003) New wave: high-tech tools to help marine reserve research. Frontiers in Ecology and the Environment 1(2): 73-79.

Redfern, J.V., Ferguson, M.C.,BeCKer, E.A., Hyrenbach, K.D., GoOd, C., Barlow, J., Kaschner, K., Baumgartner, M.F., Forney, K.A., Ballance, L.T., Fauchald, P., Halpin, P., Hamazaki, T., Pershing, A.J., Qian, S.S., Read, A., Reilly, S.B., Torres, L. And Werner, F. (2006) Techniques for cetacean-habitat modeling. Marine Ecology Progress Series 310: 271-295.

REEVES, R.R. (2000) The value of sanctuaries, parks and reserves (Protected areas) as tools for conserving marine mammals. Final report to the Marine Mammal Commission. Bethesda, Maryland, USA.

Reeves, R.R., Folkens, P.A., Stewart, B.S., Clapham, P.J. and Powel, J.A. (2002) National Audubon Society Guide to Marine Mammals of the World. New York A.A. Knopf.

Reeves, R.R., Smith, B.D., Crespo, E.A. and Notarbartolo di Sciara, G. (2003) Dolphins, whales and porpoises: 2002-2010 Conservation Action Plan for the World's Cetaceans. Gland, Switzerland and Cambridge, UK, IUCN/SSC Cetacean Specialist Group: 139pp.

ReILly, S.B. (1990) Seasonal-Changes in Distribution and Habitat Differences among Dolphins in the Eastern Tropical Pacific. Marine
Ecology Progress Series 66(1-2): 1-11.

ReILly, S.B. AND FiedLeR, P.C. (1994) Interannual Variability of Dolphin Habitats in the eastern tropical Pacific .1. Research vessel surveys, 1986-1990. Fishery Bulletin 92(2): 434-450.

Remington, N., Stevens, R.D., Wells, R.S., Holn, A., Dhungana, S., Taboy, C.H., Crumbliss, A.L., Henkens, R. and Bonaventura, C. (2007) Genetic diversity of coastal bottlenose dolphins revealed by structurally and functionally diverse hemoglobins. Gene 398(1-2): 123-131.

Rodrigues, A.S.L., ANdelman, S.J., BaKarR, M.I., Bottani, L., Brooks, T.M., CoWling, R.M., FISHPOOL, L.D.C., FonseCA, G.A.B. DA, GASTON, K.J., Hoffmann, M., Long, J.S., Marquet, P.A., Pilgrim, J.D., Pressey, R.L., Schipper, J., Sechrest, W., Stuart, S.N., Underhill, L.G., WALLER, R.W., WATTS, M.E.J. AND YAN, X. (2004) Effectiveness of the global protected area network in representing species diversity. Nature 428(6983): 640-643.

Rodrigues, A.S.L. AND GASTON, K.J. (2001) How large do reserve networks need to be? Ecology Letters 4(6): 602-609.

Rosa, S., Milinkovitch, M.C., van Waerebeek, K., Berck, J., Oporto, J., Alfaro-Shigueto, J., van Bressem, M.F., Goodall, N. and Cassens, I. (2005) Population structure of nuclear and mitochondrial DNA variation among South American Burmeister's porpoises (Phocoena spinipinnis). Conservation Genetics 6(3): 431-443.

Sanderson, E.W., Redford, K.H., Vedder, A., Coppolillo, P.B. And WARD, S.E. (2002) A conceptual model for conservation planning based on landscape species requirements. Landscape and Urban Planning 58(1): 41-56.

Scott, J.M., Murray, M., Wright, R.G., Csuti, B., Morgan, P. AND Pressey, R.L. (2001) Representation of natural vegetation in protected areas: capturing the geographic range. Biodiversity and Conservation 10(8): 1297-1301.

Soutullo, A. And Gudynas, E. (2006) How effective is the MERCOSUR's network of protected areas in representing South America's ecoregions? Oryx 40(1): 112-116.

Truda-Palazzo, J., Augustowski, M., Barreto, A.S., Engel, M., Gales, N., Garcia, R., GedamKe, P.J., Groch, K.R., IÑIguez, M., Lima, R.P. DE, Marcondes, M.C., Oosthuizen, H., Sironi, M. And Tossenberger, V. (2008) The South Atlantic: a sanctuary for whales. Paper SC60\574 rev2 presented to the IWC Scientific Committee. Santiago, Chile, June 2008. [Available from IWC Secretariat, Cambridge, UK].

UNEP-WCMC (2006) World Database on Protected Areas. Available at sea.unep-wcmc.org/wdpa.

Wares, J.P., Gaines, S.D. And Cunningham, C.W. (2001) A comparative study of asymmetric migration events across a marine biogeographic boundary. Evolution 55(2): 295-306. 
